\title{
Interactive comment on "AerGOM, an improved algorithm for stratospheric aerosol retrieval from GOMOS observations. Part 2: Intercomparisons" by Charles Étienne Robert et al.
}

Charles Étienne Robert et al.

charles.robert@aeronomie.be

Received and published: 5 August 2016

We thank anonymous referee \#2 for the review. Please see the attached supplement for our response.

Please also note the supplement to this comment:

http://www.atmos-meas-tech-discuss.net/amt-2016-27/amt-2016-27-AC3-

supplement.pdf

Interactive comment on Atmos. Meas. Tech. Discuss., doi:10.5194/amt-2016-27, 2016. 